\title{
PRECONDITIONS OF YOUNG LEARNERS' HUMANISTIC EDUCATION DURING PHYSICAL EDUCATION LESSONS
}

\author{
Rolandas Jančiauskas \\ Klaipèda University, Klaipéda, Lithuania
}

\begin{abstract}
Research background and hypothesis. Favourable conditions for children's humanistic education will occur after the implementation of the programme of junior schoolchildren's humanistic education in physical education lessons.

Research aim was to analyze the background for junior schoolchildren's humanistic education theoretically and to determine the tendencies of changes in the relationship between schoolchildren and teachers in physical education lessons.

Research methods. Literature review and questionnaire survey.

Research results. After the implementation of humanistic education program for junior schoolchildren in physical education lessons, their behavior became more humanistic, their relationship with classmates and teachers improved. Our findings coincided with those of the other authors. Junior schoolchildren's relationship particularly lack sensitivity. The findings of Group E have shown that children of that age group can already understand moral concepts and base their behavior on them. The experimental program had an effect not only on the behavior of children in Group E, but also on their teachers' behavior, which became more humanistic.

Discussion and conclusions. Junior schoolchildren's education in a humanistic, safe and functional environment which fosters sincere relationship changed the relationship between pupils and teachers, so it can be assumed that the experimental program has proved to be successful in pedagogical practice. The study shows the changes of behavior of Group E teachers who participated in the educational experiment.
\end{abstract}

Keywords: humanistic education, physical education lesson, relationship among junior schoolchildren.

\section{INTRODUCTION}

A 11 the world feels the recession of values, therefore, it is necessary to develop children's humanism from the moment they start school. According to A. Gumuliauskiene (2001), the most important age for developing person's humanistic values is young school age, as it is the period of intensive development of child's personality, their self-awareness, and relations with themselves and the world (PileckaitèMarkoviené, 2005). D. Augienè (2002) points out that social knowledge at this age is related to the understanding of friendship and the development of the contemplations of ethics; a more purposeful ambition for self-help - situational self-control and correction of one's behaviour - is noticed. Today's school faces the requirement to organise the educational process by creating humanistic relationship based on humanistic values; the main purpose of the education of a young generation is, according to V. Rajeckas (2001), the development 
of a well-rounded, democratic and humanistic personality with high national conciousness. Humanism (lat. humanus) is understood as a positive attitude towards a person, the object of love and respect; human life is the highest value; the core value of a well-rounded and mature person is communication based on humanistic relation (Bitinas, 2004), which is the base of spirituality and honesty (Bakutytè, 2001).

Humanistic education helps learners understand their needs, aquire inner freedom and develop responsibility, try to adapt humanistic values as their own values, form positive self-evaluation, encourage consciousness and activity of behaviour (Cibulskaite, 2000), and join cognitive and emotional elements of teaching. A person who is thrilled with the joy of pure emotional experience feels and expriences values as the objects of conscientious behavior (Stančienè, 2005), and experiencing a certain feeling, one is able to determine what is more or less valuable (Martišauskienè, 2001). If people strictly follow the code of morals, when they break it, they feels guilty, and if people doubt some values, they need to decide either to choose some of them or not, and the values which always get the priority are called the essential personal values (Ursery, 2005), which are already the essence of a personality and have a motivational function in everyday life.

However, according to E. Armavičiūtè (2004), there is a clear gap between what learners know about proper behaviour and their real behaviours. Therefore, the ability to make decisions takes an important place in the process of internalisation of learners' ethical values, when students have to express their thoughts about many ethical issues or etical principles, to choose one or the other manner of behaviour, and to distinguish the good from the evil (Vasiliauskas, 2005). In the opinion of B. Bitinas (2004), teaching, ethical education encourage students to behave in a humanistic way, however, solid humanistic forms of behaviour can be developed only through practice. Therefore, it is necessary to develop not only ethical attitudes, beliefs, feelings, ideals, but also behaviour, as behaviour is an important index of one's social values (Ališauskienè, 2005). According to L. Jovaiša (2001), children's humanistic behaviour and their social competences can be developed in humanistic relations between teachers and learners. Observing students activities during Physical Education lessons teachers have to react instantly to inappropriate beaviour of their students, analise and discuss it with all classmates (Knudson, Morrison, 2002; Schmidt, Wrisberg, 2004). During Physical Education lessons children should be taught approriate behaviour directly (Eldar, Ayvazo, 2009) by providing them not only with theoretical ideas which reflect humanistic behaviour, but also they should be shown how to adapt them to real situtions (Bitinas, 2004). According to M. Joniliene (2008), it is possible to observe children's efforts to solve problems, which bother them, and to stick to certain behaviour rules at play, but a teacher should notice if children do not hurt others while solving their problems. D. Hellison (1995) points out the necessity of the teacher's applied strategies, which help to impart values to children by changing the rules of a game, modelling different situations, thus children's behaviours are observed and corrected (Morris, Stiehl, 1999). When children behave in a humanistic way during Physical Education lessons, the teacher should emphasise such behaviour by praising them, thus encouraging other children to praise their peers, behave honestly, stick to the rules of a game and help to create safe environment (Sullivan, 2006).

The relevance of humanistic education is reflected in many studies by foreign and Lithuanian scientists. The problems of humanistic education are observed in different levels and aspects, however, there is no research which examines the problem of young learners' humanistic education during Physical Education lessons. This fact does not allow forming a whole view of the status of humanism during Physical Education lessons among children of this age group. After starting school, primary school learners face difficulties of socialisation (Augienè, 2002) as children often lack consideration and openness (Bakutyte, 1998). Children encounter their peers' intolerence and inability to tackle conflicts during Physical Education lessons, and the increase in children's agression is becoming a topical problem for the society (Rupšienė, Plačeniené, 2002). Therefore, it is necessary to humanise the educational process. In order to solve the problem of young learners' humanisation during Physical Education lessons, it is necessary to reorganise physical education making it more humanistic, therefore, it is important to discuss the preconditions of young learners' humanistic education theoretically and to determine changes in relations between children and teachers during Physical Education lessons.

Hypothesis. The realisation of our created humanistic programme of Physical Education 
lessons for young learners encouraging their relations based on sensitivity, openness, dignity and responsibility and expressing them in their humanistic behaviour will create favourable conditions for children's humanistic education.

Research object. Young learners' humanistic education during Physical Education lessons.

Research aim was to discuss the preconditions of young learners' humanistic education theoretically and to determine the tendencies in the changes of relations between children and teachers during Physical Education lessons.

\section{Research aims:}

1. To discuss the presumptions of young learners' humanistic education during Physical Education lessons theoretically.

2. To determine the change of relations among children and teachers during Physical Education lessons.

\section{RESEARCH METHODS}

Phylosophical, pedagogical, and psychological literature was studied, the preconditions of humanistic education during Physical Education lessons were discussed. Anonymous questionnaires were given to young learners at the beginning and the end of the educational experiment with the aim to research children and teachers' relationship and the tendencies of their changes during Physical Education lessons. The questionnaires consisted of 21 multiple choise questions. Computer programme SPSS 10.0 processed the research data. The correlational analysis of the data was conducted, the differences and the reliability and validity of the research data were determined.

Research organisation. The educational experiment was carried out in two Klaipeda schools in 2006-2007. Group E children were educated according to General Programmes and Educational Standarts of Lithuania's General School (2003) and integrated our created programme of young learners' humanistic education during Physical Education lessons. Group C children were educated during Physical Education lessons only according to General Programmes and Educational Standarts of Lithuania's General School (2003).The research used a random sample, but both Group E and C were homogeneous: 81 children from Group $\mathrm{E}$ and 82 children from Group $\mathrm{C}$ participated in the first research of the educational experiment, relatively 80 children from Group E and 80 children from Group C - in the second research. Our created programme ensured that the children were educated in humanistic, safe and functional educational environment, emphasising the value of every child as a personality. Humanistic values were imparted to children during Physical Education lessons, they were taught to communicate and collaborate. Apart from traditionally accepted knowledge of the subject, a system of positive attitudes towards different areas of knowledge was formed, and the humanistic values, were imparted by the teacher to the children in the main part of a Physical Education lesson by observing and correcting children's relationship and behaviour and in the final part of a lesson by discussing the results of the lesson.

\section{RESEARCH RESULTS}

Our created programme ensured that during the experiment the children were educated in humanistic, safe and functional educational environment; the relationship among children and teachers and its changes were researched. The second research determined that the number of Group E children who always tried to cheer their classmates $(\mathrm{Z}=$ $-3.68 ; \mathrm{p}<0.001)$ increased. Even $23.6 \%$ of Group E children and $12.0 \%$ of Group $\mathrm{C}$ always tried to cheer up their classmates when they were sad, which allows to state that the children from Group $\mathrm{E}$ became more considerate towards their classmates trying to cheer their classmates more often, than the children from Group C. There was a significant increase in the number of the children from Group E who often and always consoled their classmates $(Z=-6.248 ; p<0.001)$. As many as $22.5 \%$ of children from Group E and 3.6\% from Group C always consoled their classmates during Physical Education lessons when they failed to perform a task or activity, which means that the children in Group E became more considerate towards their classmates in a year as they consoled their classmates more often than the children from Group C. A statistically significant difference $(Z=-7.293$; $p<0.001)$ between the results of Groups $E$ and $\mathrm{C}$ in consoling their classmates was determined. The number of children from Group $\mathrm{E}$ who never helped their classmates dramatically decreased, and more children appeared who always helped their calssmates. Thus, $21.2 \%$ of Group E and $2.4 \%$ of Group C children always helped their calssmates when they failed to perform a task or activity; a statistically significant difference $(Z=-7.197$; $p<0.001)$ between the results of Groups $E$ and $\mathrm{C}$ was determined. The children from Group $\mathrm{E}$ 
became more considerate towards their classmates in a year, helping their classmates more often when they failed to perform a task or activity than the children from Group C $(Z=-6.423 ; \mathrm{p}<0.001)$. Children always want to be noticed and accepted the way they are by their peers, and, if there are no possibilities to meet these needs; they feel unsafe, which makes them act impulsively and hastily. All this decreases learning motivation and socialisation and causes behaviour problems even in primary classes. There was a significant increase in the number of the children from Group E who never hurt or offended their classmates during Physical Education lessons $(Z=-4.818 ; \mathrm{p}<0.001)$. Even $72.5 \%$ of children from Group E and $61.4 \%$ of the children from Group $\mathrm{C}$ never hurt or offended their classmates during Physical Education lessons when they failed to perform a task or activity, which allows to state that the children from group $\mathrm{E}$ became more tolerant and considerate towards their classmates than the children in Group C; a statistically significant difference $(Z=-2.033$; $\mathrm{p}<0.05)$ between the results of Groups $E$ and $\mathrm{C}$ was determined. It suggests that children from Group E became more humanistic and tolerant to their classmates in a year than the children from Group $\mathrm{C}$ as they did not hurt their classmated because of their failures.

In a year the number of the children from Group E who always shared their joy and sorrow during Physical Education lessons with their classmates increased $(Z=-3.651 ; p<0.05)$. As many as $32.5 \%$ of the children from Group $E$ and $26.5 \%$ from Group C thought that their classmates always shared their joy and sorrow with them. Other classmates were more open and shared their feelings more often with children from Group E than Group C. A statistically significant difference of the results between children in Groups $\mathrm{E}$ and $\mathrm{C}$ was determined $(\mathrm{Z}=-2.39 ; \mathrm{p}<0.05)$. We found that $73.8 \%$ of the children from Group $\mathrm{E}$ and $68.70 \%$ from Group $C$ never cheated or lied to their classmates during Physical Education lessons. Children in Group E were more honest while socialising with their classmates, they did not cheat or lie, shared their feelings and experiences with others, got on well with their classmates and behaved humanistically more often than the children from Group C. There was a significant increase in the number of children from Group E who always praised their classmates for their achievements during Physical Education lessons $(Z=-5.3 ; p<0.001)$. We saw that $22.5 \%$ of the children from Group E and 8.4\% from Group C always praised their classmates for their achievements, which means that children in Group E became more considerate and attentive to their classmates in a year, praising them more often than the children from Group C. A statistically significant difference of the results between Groups $\mathrm{E}$ and $\mathrm{C}$ was determined $(\mathrm{Z}=-5.64$; $\mathrm{p}<0.001$ ). However, the number of the children in Group $\mathrm{C}$ who always praised their classmates for their ahievements during Physical Education lessons decreased $(Z=-2.7 ; p<0.05)$. As may as $28.8 \%$ of the children from Group E and $30.1 \%$ from Group $\mathrm{C}$ never boasted during Physical Education lessons, and $63.8 \%$ of the children from Group E and 67.5\% from Group C never reminded their classmates of their previous failures.

The number of the children from Group E who claimed that their teacher always listened to their opinion increased in a year $(Z=-3.359$; $\mathrm{p}<0.001$ ), and $43.8 \%$ of the children from Group E and $28.9 \%$ from Group C said that teachers always listened to their opinions during Physical Education lessons, which might mean that the teachers of Group E tried to listen to the opinions of their students more often than the teachers in Group C $(Z=-3.237 ; p<0.001)$. While listening to their students'opinion, teachers taught the children to be more understanding and tolerant and thus developed their humanism. The analysis the results of Group C showed, however, that the number of cases when teachers always listened to their students'opinions decreased significantly $(p=0.000)$. In the opinion of children from Group $\mathrm{E}$, there were significantly more teachers who always noticed their students' bad mood and comforted them $(Z=-4.903 ; p<0.001)$. Even $33.8 \%$ of teachers in Group E and $21.7 \%$ of group $\mathrm{C}$ always noticed their students' bad mood and comforted them. It may mean that the teachers of Group E noticed their students' bad mood and comforted them more often than the teachers of Group C $(Z=-3.189 ; p<0.001)$.

There was a significant growth in the number of teachers of Group E who often or always consoled their students in case of failure $(Z=-4.771$; $p<0.001$ ): $33.8 \%$ of children from Group $E$ and $19.3 \%$ from Group C thought that their teachers always consoled their students when they failed to perform a task or activity. This fact allows presuming that teachers in Group E consoled their students more often during Physical Education lessons than teachers in Group C $(Z=-4.025$; 
$p<0.001)$. However, discussing the results of Group C, it appeared that the number of teachers who always comforted their students in case of failure decreased $(Z=-2.448 ; p<0.05)$. On the other hand, in the opinion of children from Group $E$, the number of teachers who always helped their students in case of failure increased $(Z=-5.025$; $\mathrm{p}<0.001$ ), as $47.5 \%$ of children in Group E and $26.5 \%$ in Group C thought that teachers always helped their students in case of failure during Physical education lessons, which means that teachers in Group E helped their students more often when they failed than teachers in Group $C$ $(\mathrm{Z}=-4.626 ; \mathrm{p}<0.001)$. Analysing the research results of the children from Group C, it appeared that the number of teachers who always helped their students in case of failure decreased $(Z=-2.316$; $\mathrm{p}<0.05)$ The children from Group E claimed that the number of teachers who never shared their mood with their students decreased, but the number of those who always shared their mood with their students slightly increased $(Z=-3.93$; $\mathrm{p}<0.001$ ), as $21.3 \%$ of the teachers of Group E and $12.0 \%$ of Group $\mathrm{C}$ always shared their mood with their students during Physical Education lessons. This means that teachers in Group E were more open and sincere with their students than Group $\mathrm{C}$ teachers $(\mathrm{Z}=-4.445 ; \mathrm{p}<0.001)$. However, analysing the reseach data of Group $C$, we found that the number of teachers who never shared their mood with their students increased during the second research $(Z=-1.978 ; p<0.05)$.

The children in Group E thought that the number of teachers who always praised their students for their achievements during Physical Education lessons increased significantly ( $\mathrm{Z}=$ $-2.761 ; p<0.01)$. Children said that $46.3 \%$ of the teachers of Group E and $31.3 \%$ of Group C always praised their students for their achievements during Physical Education lessons, which means that teachers in Group E became even more considerate to their students in a year by praising them more often for their achievements than teachers in Group $\mathrm{C}(\mathrm{Z}=-3.37 ; \mathrm{p}<0.001)$. We found that $82.5 \%$ of children in Group E and $74.7 \%$ in Group $\mathrm{C}$ thought that teachers never riminded their students of their previous failures, $20.0 \%$ of children from Group E and $43.4 \%$ of Group C thought that teachers never allowed their children to choose their sport activities, which might mean that teachers of Group E were more considerate and attentive to their students by listening to them more often and allowing them to choose their sport activities themselves than teachers of Group C $(Z=-3.619 ; p<0.001)$. In a year the number of teachers of Group $\mathrm{E}$ who never made their students did what they did not want during Physical Education lessons significantly increased $(Z=-2.85 ; p<0.01)$, they were more considerate to their students than Group $\mathrm{C}$ teachers.

\section{DISCUSSION}

After the implementation of young learners' humanistic education programme during Physical Education lessons, children's behaviour became more humanistic, their relationship with their friends and teachers improved. At the end of the experiment children in Group E tried to listen to, conform, console, cheer and help their classmates more often, they more frequently shared their joy and sorrow, praised others for their achievements in Physical Education lessons than children in Group C, who were less considerate to their classmates. Our research results conform to R. Bakutyte's (2001) research data that young learners' relationship especially lack consideration. The research showed that other classmates were more open with the children from Group E, sharing their joy and sorrow with them because children in Group E did not lie and cheat, did not remind their classmates of their previous failures. The behaviour among the children in Group C, however, changed little in a year. The relations of children in Group C still lacked consideration and understanding. The results obtained from Group C correspond to the ones by R. Ališauskienè (2005), D. Augienè (2002) as it is difficult for primary school learners to listen to their friends, confort, sympathyse and help them. E. Martišauskienè (2001), N. Cibulskaite (2000) research data show that the relationship of both younger and older adoloscents are not considerate enough, and, according to V. Aramavičiūtė (2004), adoloscents do not fully understand the meaning and essence of some ethical values, for this reason, they worry too little about them and do not try to realise them in practice.

Even though the children from Group E were provided with theoretical knowledge about humanistic values and humanistic behaviour during the educational experiment, there were some children in Group E, as in many cases in Group C, whose behaviour had not changed after a year. Our results correspond with the opinion of Lithuanian and foreign scientists (Bakutyte, 1998; Nunner-Winkler, Sodian, 1988) 
that children of that age and their feelings are based on hedonistic selfishness, thus they are not able to understand fully the essence of ethical concepts as they are too complicated for children, and children's understanding is limited by too little life experience; as well as with T. Malti and M. Keller's (2009) opinion that the behaviour of primary school learners is adversily related to the knowledge of ethical concepts, therefore, children's agression can be related to the lack of ethical knowledge (Stams et al., 2006). On the other hand, according to J. Smetana and M. Killen (2008) and our research results of Group E children, the children of this age are already capable of understanding ethical concepts and they ground their behaviour on them. A lot of other scientists (Krettenauer et al., 2008; Malti et al., 2009) think that moral decisions and expression of emotions can be related to personal behaviour.

Our created experimental programme of humanistic education, applied during the educational experiment, influenced not only the behaviour of children in Group E, but also of their teachers. They became more humanistic and tried to listen to their students' opinion, notice children's bad mood, comfort, console and help them when they failed to perform a task or activity, and to praise them for their achievements during Physical Education lessons more often than Group $\mathrm{C}$ teachers. Our research results corresponded with R. Bakutyte (1998), R. Vitkauskas (2004) research data that Group E teachers were most attentive to their students, helped them when necessary and addmitted their own mistakes. The majority of Group E educators tried to follow the direction of humanistic education, which encourages children's self-actualisation, and humanistic relationship with their students was based on respect and trust, which could encourage the development of children's social skills and their humanistic behaviour during Physical Education lessons.

\section{CONCLUSIONS AND PERSPECTIVES}

When young learners are educated in humanistic, safe and functional environment, which enshrines sincere relationship between teachers and children, students' relationship with their classmates and teachers becomes more humanistic, which allows assuming that the application of the experimental programme in pedagogical practice has served the purpose.

At the end of the experiment children in Group E helped, comforted their classmates during Physical Education lessons when they failed to perform a task or activity more often than children in Group C. Thus we suggest that imparting knowledge about humanistic values to children in Group E during Physical Education lessons, helping students to feel and experience these values, and choose humanistic behaviour based on them, changed their behaviour into more humanistic one.

The research showed that the behavior of Group E teachers, who participated in the experiment, became more humanistic as well.

\section{REFERENCES}

Ališauskienè, R. (2005). Mokinių jautraus elgesio mokykloje raida nuo pradinio mokyklinio amžiaus iki paauglystès. Pedagogika, 80, 120-124.

Aramavičiūtè, V. (2004). Dvasingumas: brandos ypatumai ir prielaidos vyresniajame mokykliniame amžiuje. Pedagogika, 72, 10-19.

Augienė, D. (2002). Jaunesniojo mokyklinio amžiaus mokinių socialinio pažinimo plètros ypatumai. Pedagogika, 61, 5-9.

Bakutytė, R. (2001). II-IV klasių mokinių humaniško elgesio su artimiausiais aplinkos žmonėmis bruožai. Pedagogika, 54, 12-18.

Bakutytė, R. (1998). II-IV klasiu mokiniu humaniškumo ugdymas: daktaro disertacija. Šiauliai: Šiaulių universitetas.

Bitinas, B. (2004). Hodegetika. Auklejjimo teorija ir technologija. Vilnius: Kronta.

Cibulskaite, N. (2000). Matematikos mokymo humanizavimas $V$-je pagrindinès mokyklos klasejje: daktaro disertacija. Vilnius: VPU.

Eldar, E., Ayvazo, S. (2009). Educating through the physical-rationale. Education \& Treatment of Children, 32, 471-486.

Gumuliauskienė, A. (2001). Jaunesniujų moksleivių savęs vertinimo ypatumai kaip socialinès brandos apraiškos. Pedagogika, 54, 79-85.

Hellison, D. (1995). Teaching responsibility through physical activity. Champaign, IL: Human Kinetics.

Joniliené, M. (2008). 4-6 metu vaikų doro elgesio ypatumai. Pedagogika, 90, 136-141.

Jovaiša, L. (2001). Ugdymo mokslas ir praktika: analitiniu straipsniu monografija. Vilnius: Agora.

Knudson, D. V., Morrison, C. S. (2002). Qualitative Analysis of Human Movement. Champaign IL: Human Kinetics.

Krettenauer, T., Malti, T., Sokol, B. W. (2008). The development of moral emotion expectancies and the happy victimizer phenomenon: A critical review of theory and application. European Journal of Developmental Science, 2, 221-235.

Malti, T, Gummerum, M., Keller, M., Buchmann, M. (2009). Children's moral motivation, sympathy, and 
prosocial behaviour. Child Development, 80 (2), 442 460.

Malti, T., Keller, M. (2009). The relation of elementaryschool children's externalizing behaviour to emotion attributions, evaluation of consequences, and moral reasoning. European Journal of Developmental Psychology, $6(5), 592-614$.

Martišauskienė, E. (2001). Emocinė vertybių internalizacija paauglysteje. Pedagogika, 55, 19-26.

Morris, G. S. D., Stiehl, J. (1999). Changing Kids' Games (2nd ed.). Champaign, IL: Human Kinetics.

Nunner-Winkler, G., Sodian, B. (1988). Children's understanding of moral emotions. Child Development, $59,1323-1338$.

Pileckaitè-Markovienė, M. (2005). Santykių su bendraamžiais ir vidinès darnos sąsajos jaunesniame mokykliniame amžiuje. Ugdymo psichologija, 14, 7-12.

Rajeckas, V. (2001). Ugdymo tikslo samprata. Pedagogika, $55,10-13$

Rupšienė, L., Plačenienė, D. (2002). Vaikų agresyvumas: šiuolaikinès pradžios mokyklos problema ir jos sprendimo gairès. Pedagogika, 59, 37-44.

Schmidt, R. A., Wrisberg, C. A. (2004). Motor Learning and Performance: A Problem-based Learning Approach. Champaign, IL: Human Kinetics.

Smetana, J., Killen, M. (2008). Moral cognition, emotions, and neuroscience: An integrative developmental view. European Journal of Developmental Science, 2, 324-339.

Stančiené, D. M. (2005). Dorovinių galių fenomenologinė ižvalga: vertybinis ugdymo aspektas. Pedagogika, 79, 46-48.

Stams, G. J., Brugman, D., Dekovic, M. et al. (2006). The moral judgment of juvenile delinquents: A meta-analysis. Journal of Abnormal Child Psychology, 34, 697-713.

Sullivan, E. C. (2006). Character Education in the Gymnasium: Teaching More than the Physical [2010 02 20]. Internet link: http://web.ebscohost.com/ehost/ detail vid=26\&hid=12\&sid=40b20f72-7ef7-449d-8e22806 efde 53 e $3 \mathrm{~b} \% 40$ sessionmgr 11\&bdata $=$ JnNpdGU9ZWh vc3QtbGl2ZQ\%3d\%3d\#db=trh\&AN=25387949.

Ursery, D. (2005). Moral Reasoning Guidelines [2010 03 29]. Internet link: http://www.stedwards.edu/ursery/ guide.htm.

Vasiliauskas, R. (2005). Mokymo turinio ittaka kuriant mokinio vertybiu sistemą. Pedagogika, 77, 20-24.

Vitkauskas, R. (2004). Mokytojo dvasingumo apraiškos muzikinio ugdymo realybejje. Pedagogika, 72, 161-165.

\title{
JAUNESNIOJO MOKYKLINIO AMŽIAUS VAIKŲ HUMANIŠKUMO UGDYMO KŪNO KULTŪROS PAMOKOSE PRIELAIDOS
}

\author{
Rolandas Jančiauskas \\ Klaipèdos universitetas, Klaipéda, Lietuva
}

\section{SANTRAUKA}

Tyrimo pagrindimas ir hipotezė. Pedagoginèje praktikoje realizuojant mūsų parengtą jaunesniojo mokyklinio amžiaus vaikų humaniškumo ugdymo(-si) kūno kultūros pamokose programą, kūno kultūros pamokose kuriant jautrumu, atvirumu, orumu ir atsakingumu pagrịstus jaunesniojo mokyklinio amžiaus vaikų tarpusavio santykius, susidarys palankios sąlygos vaikų humaniškumui ugdyti.

Tikslas: teoriškai aptarti jaunesniojo mokyklinio amžiaus vaikų humaniškumo ugdymo prielaidas bei nustatyti vaiku ir mokytojų tarpusavio santykių kaitos tendencijas kūno kultūros pamokose.

Metodai. Literatūros apžvalga ir anketinè apklausa.

Rezultatai. Igyvendinus jaunesniojo mokyklinio amžiaus vaikų humaniškumo ugdymo(-si) kūno kultūros pamokose programą, vaikų elgesys tapo humaniškesnis, pagerèjo jų santykiai su klasės draugais ir mokytojais. Mūsų tyrimo rezultatai sutapo su kitų autoriu gautaisiais - jaunesniojo mokyklinio amžiaus vaikų tarpusavio santykiuose ypač stinga jautrumo. Visgi mūsų tyrimo rezultatai E grupéje parodẻ, kad šio amžiaus vaikai jau gali suprasti dorovines sąvokas ir jomis gristi savo elgesí. Eksperimentinè programa turëjo įtakos ne tik E grupès vaikų, bet ir jų mokytojų elgesiui, kuris tapo humaniškesnis.

Aptarimas ir išvados. Jaunesniojo mokyklinio amžiaus vaikams ugdantis humaniškoje, saugioje ir funkcionalioje aplinkoje, kurioje buvo puoselejjami nuoširdūs vaikų ir mokytojų tarpusavio santykiai, pasikeitè ugdytinių santykiai su klasès vaikais ir mokytojais humaniškumo linkme. Taigi galima daryti prielaidą, kad eksperimentinès programos taikymas pedagoginejje praktikoje pasiteisino. Tyrimo metu buvo nustatyti ir E grupès vaikų mokytojų, dalyvavusiu ugdomajame eksperimente, elgesio pokyčiai su savo klasės auklètiniais humaniškumo linkme.

Raktažodžiai: humaniškumo ugdymas, kūno kultūros pamoka, jaunesniojo mokyklinio amžiaus vaiku tarpusavio santykiai. 